\title{
Analysis of Development of De-radicalization of Terrorist Prisoners in the Correctional Institutions In Indonesia
}

\author{
Yusril Arinaldy Asdira ${ }^{1^{*}}$ \\ ${ }^{1}$ Politeknik Ilmu Pemasyarakatan \\ *Corresponding author, e-mail: arinaldyasdira@gmail.com
}

Received 2020-03-28;

Revised 2020-04-26;

Accepted 2020-05-02;

Published Online 2020-05-30

\section{Conflict of Interest Disclosures: \\ The authors declare that they have no significant competing financial, professional or personal interests that might have influenced the performance or presentation of the work described in this manuscript.}

\begin{abstract}
Terrorism is a problem that requires special handling, one of which is by fostering deradicalization. In Indonesia according to data obtained that de-radicalization is considered unsuccessful because there are still many terrorists who dare to commit acts of terrorism even though many other terrorists have been arrested. One of the indications is like the North Sumatra Poltabes office-bombing incident in November 2019 where the Police arrested 74 suspected terrorists involved in the suicide bombing. This study aims to determine the various activities carried out for deradicalisation guidance and to see the achievements of deradicalization coaching. The research method used is descriptive qualitative research method with literature study approach. The results show that various activities have been carried out by the government one of them is create BNPT a special institution to manage and implement deradicalization of terorrism prisoners through soft approach to deradicalize terrorist prisoners by reshaping their thinking about the struggle against religion. The conclusion is that the development of deradicalization of terrorist prisoners in Indonesia has been carried out by various parties, but based on the results of this study and previous research is still not optimal so it needs to be reviewed about the type or method of fostering deradicalization that is appropriate.
\end{abstract}

Keywords: Deradicalization, Prisoners, Terrorism, Correctional Institution

\section{Introduction}

Terrorism is a very real threat to the world community, including the nation and state of Indonesia. At this time, according to data, there are 557 terrorism prisoners spread across 33 regional offices (Ditjenpas, 2020). The issue of terrorism in Indonesia only received serious attention after the Bali bombing tragedy in 2002. As an effort to eradicate terrorism, restore the nation's image in the eyes of the world, and ensure the safety of its inhabitants, the Government of Indonesia through the Republic of Indonesia National Police, formed a task force the bomb (which later became the forerunner to the formation of Anti-Terrorism 
Detachment 88) assigned to deal with and uncover the tragedy. Indonesia also issued Perpu No. 1/2002 concerning the eradication of criminal acts of terrorism (which was later stipulated as Law of the Republic of Indonesia No. 15/2003). Since the tragedy, the Republic of Indonesia National Police have succeeded in arresting, prosecuting, and imprisoning terrorism actors.

However, arrest, trial, and imprisonment alone are not effective enough to rehabilitate convicted terrorism cases. Because, from the number of prisoners of terrorism cases who have been released, there are some of them who then rejoin the radical terrorist groups, and resume their terrorist activities after being released from prison. In fact, there are also terrorism prisoners who then spread their radical ideology to other prisoners (ICG, 2007). This shows that handling terrorism that only relies on a legal approach is not enough to overcome the problem completely. The approach, also known as the hard approach, is considered to be unable to completely rehabilitate the radical ideology believed by terrorism inmates because it lacks the personal aspects of the individual.

The Bali bombing in 2002 has been a lesson that is important for Indonesia, especially for the police, not only about the investigation and the investigation of terrorism cases but how the business of deradicalizing it becomes an important part in the face of terrorism. If it can prevent terrorism was certainly more important, than the ability to catch the terrorists who are already doing the bombing that killed many people. Then it is necessary to ascertain what programs that could be implemented in deradicalization programs to prevent casualties caused by acts of terrorism occurred again (Suryani, 2017).

Terrorism is not a term that is rarely heard and read but it is very commonly known by the public at large and also reported in various mass media, both newspapers, radio, television and online media including social media. The contents of the news, both in the form of direct statements by police officials, politicians and experts published. The term or word terrorism is becoming more popular in the global public, especially after the terror that attacks the tower (Suryani, 2017).

In Indonesia itself, for the handling of terrorism in Indonesia, it can lead to repressive legal actions because it has the potential to strengthen radical understanding of acts of terrorism so that to punish the goal of eradicating terrorism, it is necessary to attempt to eradicate the radical thinking of the perpetrators by carrying out de-radicalization (Mareta, 2018).

Global attention was drawn to Indonesia when a suicide bomb attack occurred in Bali in October 2002 that killed around 202 civilians. After the attack, in 2003 happened again bombing Marriott in Jakarta, then in the 2004 bombings by using car bombs at the Embassy of Australia, 2005 back again bombings in Bali and 2009 suicide bombing at the Hotel Marriott and Ritz Carlton Jakarta . According to news and police investigations that Jemaah Islamiyah (JI) is the culprit. JI is an Islamist group that is linked to AlQaeda and adheres to the Salafi-Ji understanding of hadism. These JI followers believe that carrying out violent jihad is the right way and does not violate religion to fight the enemies they perceive (Syafiq, 2019)

In general, there are two psychological approaches that are often used to estimate the reasons a person or group commits acts of terrorism, namely the syndromic approach and instrumental approach. The Syndrome approach views acts of terrorism as manifestations of specific psychological constructs that can be identified, such as certain personality types, social backgrounds, ideologies, and so on. Meanwhile, the instrumental approach explains acts of terrorism as a means to an end (Kruglanski \& Fishman, 2009). For example, the desire of terrorists to free their nation from tyranny or defend their religion can defeat their attention on other desires, such as protecting the innocent or fostering religious harmony. The reason they put forward is that only violence can overcome a problem and can help them achieve their goals which of course they think is right (Kruglanski \& Fishman, 2009).

Proving an instrumental approach to terrorism cases in Indonesia, Ali Imron as the Bali bombers explained in his book the reasons underlying his actions: (1) dissatisfaction with the current government, (2) widespread damage, namely damage to the faith (belief in one God Almighty) and thought, and moral decay, (3) hope to permit jihad fi sabilillah (physical war), (4) perform jihad obligations, and (5) retaliation against infidels. Ali Imron revealed that Israel had committed inhuman acts against Palestinians, and also non-Muslims against Muslims. He revealed this problem as a basis for his group to retaliate against those who they consider hostile and at war with Islam. (Salenda, 2009)

The Indonesian government prefers to use cultural aspects as a tool to find solutions to immediately change the mindset of terrorist prisoners. The cultural approach has been used because of humane and 
developing ways of bonding, which are believed by each other to disrupt the spread of radical ideologies and reduce prisoners and extremist characters in prisons one of them by deradicalization (Suratman, 2018). Meanwhile, according to $(\mathrm{CNN}, 2019)$ that the program deradicalization which applied to convicts terorism still not able to return the prisoners are terrorists $\mathrm{d}$ i Indonesia to the right path as a whole.

As Quoted by (CNN, 2019) terrorism observer from the University of Indonesia Ali Abdullah Wibisono stated that only 30 percent of terrorist convicts changed after undergoing the de-radicalization program. He explained that the deradicalization on system applied in detention was ineffective. He gave an example if someone who is exposed to radicalism is only confined, then there is not much that a person can do. That condition is said to make prisoners think of the concepts of extremism and radicalism in detention cells. The same thing happened to women and children who were exposed to radicalism. One way to return them back to Indonesia, Ali said, was to provide another alternative to life. The government must be able to convince them that life as citizens is far better than the following radicalism. (CNN, 2019).

(Ashour, 2009) defines deradicalization as the process by which radical groups reverse their ideology and legitimize the use of violent methods to achieve political objectives while moving towards accepting gradual, political and economic change in a pluralistic context (Suratman, 2018).

This makes de-radicalization different from disengagement because it involves an approach to building conductive dialogue for prisoners. Therefore, there are many claims that de-radicalization is a significant strategic tool in tackling terrorism, and is surprisingly carried out by many countries (Suratman, 2018).

To overcome the threat of terrorism, Indonesia has used a de-radicalization approach. Aside from Indonesia, this de-radicalization program is also developing in various countries to fight the development of acts of terrorism triggered by radical religious ideologies. For example, programs carried out by several countries in the Middle East such as Saudi Arabia, Yemen, Egypt, and Algeria; in Southeast Asia such as Singapore, Malaysia, and Indonesia. While in Europe such as Britain, the Netherlands, and Denmark.

According to research conducted by (Mareta, 2018), The use of violence in dealing with terrorism does not succeed in solving the problem of terrorism to its roots so that efforts are needed to change the radical thinking of the perpetrators by deradicalizing. Deradicalization of terrorism prisoners has various obstacles including uncooperative prisoners and lack of supporting facilities. Success parameters of de-radicalization are needed to strengthen and evaluate the results of rehabilitation of terrorism prisoners so that this research is important to do. This study uses qualitative research methods by collecting primary and secondary data. The results of the study describe terrorism as an individual problem that requires special coaching according to the individual principles of coaching, and stages in the implementation of rehabilitation of terrorism prisoners so that in implementing effective rehabilitation requires the participation of prisoners and facilitators, the availability of procedures and coaching modules, and evaluation of the success of rehabilitation of terrorism prisoners (Mareta, 2018).

Deradicalisation is to detect early, deter from the beginning, and target various potential layers with various forms and variants that are relevant for each target group (Setara, 2012). As a transnational crime, terrorism is seen as a real threat to security and stability. Therefore, he seized a lot of attention from various actors, including state actors. Efforts to overcome this were carried out in various ways, including deradicalization. Deradicalization itself has several waves based on the time of its implementation. The first wave was carried out from 2002 to 2004, while the second wave took place from 2005 to 2010, and the third wave took place after 2010. The implementation of de-radicalization in various waves including "unique", because it always includes religious rehabilitation programs, because of their belief that basically everything kinds of terrorism based on ideology. (EL-Said, 2017)

Although the de-radicalization program has been launched by the Indonesian government, questions and criticisms still arise. The International Crisis Group (ICG), for example, recommends that the Government of Indonesia accelerate efforts to implement a system under the Directorate of Corrections to identify and monitor high-risk detainees, both while in custody and after their release.4 Furthermore, ICG recommends increasing supervision through capacity building analytical correction staff. (ICG, 2012)

Terrorism is a problem that requires a separate handling policy. Many terrorists were arrested and received prison sentences. (Isnanto, 2018)

To overcome the problem of the occurrence of more terrorism in Indonesia, the terrorist inmates were carried out de-radicalization. This research will discuss various steps taken in conducting deradicalisation 
training for terrorist prisoners in Indonesia and also find out what the role of fostering deradicalization is. (Suarda, 2016)

The important thing to be discussed further is whether the programs and policies on terrorism development with deradicalization are appropriate and have succeeded in reducing the amount of terrorism in Indonesia or not. Therefore I was interested to conduct a research under the title "Analysis of The Deradicalization of Terrorist Prisoners in Correctional Institutions in Indonesia".

\section{Method}

This study used qualitative approach which according to (Bilken \& Bodgdan, 2001) is a method of research by gathering information, formulating related questions and then linking with related theories and concepts. One of the characteristics of qualitative research is that researchers act as instruments as well as data collectors. By using the secondary data such as questionnaires, interview guidelines, observation guidelines, etc can also be used, but their function is limited to supporting the researcher's task as a key instrument (Moleong, 2007).

Data collection techniques are carried out through library studies, namely by collecting journals that discuss the deradicalization, collecting data on the number of terrorist prisoners in Indonesia through the Direktorat Jendral Pemasyarakatan, and also reading various news that discusses the deradicalization program and also how the development and successful implementation of the deradicalization program in Indonesia. Data was collected to be analyzed and drawn a conclusion.

\section{Results and Discussion}

\section{A. The Root of Radicalization in Indonesia}

(Horgan, 2008) explains that there are steps to a person's involvement in terrorism, which consists of a complex process consisting of the following three phases: (1) joining a terrorist group, (2) living inside a terrorist group, and (3) leaving, stop, or break away from terrorist groups whether or not followed by the process of deradicalisation. Some researchers explain that the motivation of someone to become a terrorist or to join a terrorist group varies greatly. Therefore, the leaders or members of the group or the terrorist network may have ulterior motives, targets and strategies are different from each other. (Horgan, 2008)

According to research conducted by Sukabdi (2015), there are many factors that motivate individuals to engage in acts of terror in Indonesia. These factors can be classified into six motives:

a. Ideological religions, i.e., building the ideals of a government or religious-based society (the establishment of dawlah islamiyah or the application of sharia) where violence or terrorist acts are considered as a legitimate way to achieve these ideals

b. Driven by solidarity, which is to express empathy or help fellow believers, especially when they are threatened or victimized in conflict situations

c. The search for revenge, which is to join in terrorist acts in an effort to retaliate against the enemy for the loss (life or property) experienced by the perpetrators or their families,

d. Separatists, namely to achieve political objectives to establish a separate state.

e. The mentality of the masses, which is to participate spontaneously in acts of violence or terrorism without a clear reason, other than to follow others in the action, and

f. Situational, i.e. engaging in terrorist acts by force (Sukabdi, 2015).

Time has shown that reality is far more complex than can be conveyed by a single definition and that there are still many fields that need to be explored. 
Radicalization is further explained as a complex, dynamic, and non-linear process of change in an individual's mindset that leads from time to time to significant changes in world view, perceptions of external events, and/or their internal understanding of them. When these changes occur, they can be reflected in individual behavior, which can ultimately increase to the point of being involved in violence, violent extremism, or terrorism.

Bomb attacks in Indonesia began in 2000 with church targeting, followed by several suicide bombings until 2005. Based on the number of casualties and international impacts, the most notable attacks were: the first Bali bombing in 2002; the first Marriot Hotel bombing in Jakarta in 2003; the bombing of the Australian Embassy in 2004; and the second Bali bombing in 2005. As a result of further investigations, in November 2005, the Indonesian National Police (Polri) killed one of the most important masterminds behind this bombing attack Dr. Azahari Husin. Between 2005 and 2009 bomb attacks were successfully controlled by the National Police, and Indonesia did not experience inside bombings during this period.

Data on the exact number of convicted terrorists in Indonesian prisons varies between reports or articles. In some articles, it is estimated that more than 300 people were sent to prison in 2007, while Ungerer estimates that around two-thirds of the nearly 600 suspects were sentenced between 2000 and 2010. Although there are different time frames, inconsistent data reported in the sources this source is confusing. On the official website of the Direktorat Jendral Pemasyarakatan, the number of newly convicted terrorists was presented after 2011. The number of terrorist detainees in 2011 to 2015 were 10.942, 20.443, 27.644, 27.745, and 21.646. Data shows that in August 2013 the number of terrorism prisoners had increased to become terrorist prisoners almost triple the amount in August 2011.

These prisoners are not isolated in one or two special prisons but are scattered in several prisons in the provinces. As of August 2015, data showed that 216 terrorist convicts were scattered in 33 prisons and detention centers throughout the island. Nusakambangan Prison holds the largest concentration of terrorist inmates in 37 people, followed by Cipinang Prison in 23 people. Besides, data shows that there is only one female terrorist detained in Indonesian prison.

Data on the level of recidivism among those involved in acts of terrorism in Indonesia, by contrast, is unclear. Indeed, official data on recidivism relating to acts of terrorism are not yet available. As explained, the Indonesian government claims that many convicted terrorists repeat acts of terrorism.

Terrorist detainees are not the same as other criminals. Instead, they are special because this type of prisoner carries ideology. A review conducted by Pressman and Flockton confirms that there are significant differences between terrorists, brutal extremists, and non-terrorists. ideologically motivated violators of violence. Pressman and Flockton point out that although terrorists and brutal extremists have similarities in using violence for further political, religious and ideological purposes, the actions of brutal extremists usually do not have "the intention to cause fear and terror to civilians."

\section{B. The deradicalization program in Indonesia}

Deradicalisation is any attempt to neutralize radical notions through interdisciplinary approaches, such as law, psychology, religion, economics, education, humanity, and socio-culture for those who are influenced or exposed to radical and/or non-violence. To overcome this problem, the deradicalization program for terrorist detainees has been instituted by the Indonesian government. Claims on the manifestation of the deradicalization program can be seen from the book Deradicalization of Terrorism written by Petrus Reinhard Golose, a police officer (once a Director of Enforcement at BNPT) who is often directly involved in various terrorist operations in Indonesia. Golose said that the Indonesian police were the perpetrators of the de-radicalization program. It is they who carry out a deradicalization program against detainees involved in terrorism crimes. This program is called a form of police soft approach in handling terrorism cases. This approach has been used by the police since the 2002 Bali Bombing case in terms of interrogation techniques (Mariamah, 2013).

Meanwhile, Omar Ashour, an expert on Egyptian terrorism, states that de-radicalization is a process within the Islamist movement in which radical groups transform their ideas and do not use violent methods/methods to achieve their political goals while moving to accept political changes, economic and social gradual in the context of pluralism. (Ashour, 2009). 


\section{The formation of BNPT}

In 2010, the Indonesian government inaugurated the formation of the BNPT whose task was to develop national policies, strategies and programs in the field of combating terrorism. BNPT then has the authority to compile operational steps that include aspects of deterrence, prevention, mitigation, stopping, settlement, and all legal actions needed for related agencies to eradicate acts of terrorism quickly, integratedly and effectively by becoming the main agent involved directly in the formulation of policies \& programs, formulation of strategies, and coordinators between stakeholders, ministries, institutions, or related agencies.

In its implementation, the deradicalization program is under the responsibility of BNPT Deputy I in the areas of prevention, protection and deradicalization. The program was carried out through seven interrelated approaches to get comprehensive results. Such as religious, psychological, socio-cultural, economic, legal, political, and information technology approaches.

The implementation of the deradicalization program in Indonesia, formulated by BNPT, has two classifications. First is the deradicalization program in prisons carried out through the stages of identification, rehabilitation, reeducation, reconciliation, as well as observation and evaluation. This program targets terrorist convicts who are currently serving their terms of detention. The second is a deradicalization program outside prison which is carried out through the stages of identification, counterradicalism development, observation, and evaluation. This program targets former prisoners of terrorism cases and community groups who are vulnerable to the influence of radical ideology (BNPT, 2013)

Implementation of the Deradicalization Program (Guidance) can be done through Deradicalization in correctional institutions. with the target of terrorism prisoners who are in prison by identifying, rehabilitating, re-educating and re-socializing. Deradicalization outside the prison with the target of radical potential, ex-convicts, their families, and networks by identifying, fostering national and religious oversight and fostering independence.

Based on Presidential Regulation No. 46 of 2010, BNPT or The National Counter Terrorism Agency defines deradicalization as all efforts to transform radical beliefs or ideologies into non-radical ones through a multi and interdisciplinary approach through identification, rehabilitation, reeducation, and resocialization programs for suspects, prisoners, ex-convicts, and their families and networks indicated radically by promoting the principles of empowerment, human rights, rule of law and equality (Isnanto, 2018).

\section{Benefits of Deradicalisation Development}

Indonesia's deradicalization program for terrorist detainees has been carried out by correctional institutions or other government institutions such as the Indonesian National Police Force. Deradicalization program in Indonesian prisons can be identified by several activities such as providing conflict management training (CMT) or inviting a cleric from the Indonesian Ulama Council (MUI) to deliver a speech and discussion with terrorist detainees. However, there are some prisons that detain convicted terrorists who do not have a specific deradicalization program as identified. Deradicalization program strategy with making terrorist prisoners held at police headquarters in Jakarta and former terrorist prisoners who have renounced violence without looking at the backgroung to rethink the armed struggle.

Indonesia is often cited as an example of a country that seeks to bring about a step towards the deradicalization of prison or former prisoners of terrorism. Deradicalization is claimed by the Indonesian government as an effective means of combating terrorism.

Also, a soft approach to investigations in Indonesia is carried out to make terrorists willing to open their mouths with the promise of compensation in the form of leniency or amnesty for prison terms. Thus, based on the examples above, what is claimed to be a deradicalization program actually tends to be transactional. The aim is to dismantle the network and for that the soft approach referred to as part of the "deradicalization program" is carried out (Mariamah, 2013)

Based on the results of the study it can be explained that the deradicalization in Indonesia has already been done by the government. Not all violence can be extinguished through violence. Counter-terrorism requires comprehensive policies both at the policy level and the general and comprehensive counter- 
terrorism implementation. Basically, terrorism countermeasures are not only related to prosecution but also related to other aspects involving other agencies, such as the Ministry of Home Affairs, Ministry of Foreign Affairs, Ministry of National Education, Ministry of Law and Human Rights, Ministry of Social Affairs, Ministry of Religion, Ministry of Communication and Information, BIN, elements of the TNI in the region, as well as other elements. Other stakeholders, such as non-government organizations, universities, religious leaders, and community leaders, also need to be involved (Royani, 2013).

The implication of this research is the government of Indonesia must realize that the correctional institution is expected to be able to increase the ability and number of officers assigned to guide terrorism prisoners. One step that can be taken is to provide training and courses for terrorist prisoners so that their mindsets can change and develop for the better. The correctional institutions can also collaborate with more parties who are competent in conducting coaching including Psychologists, Anthropologists, Criminologists, and others. It is also recommended to the correctional institutions to be more active in establishing cooperative relations with various agencies and institutions that can help improve the quality of programs implemented for deradicalizing terrorist prisoners. For example with the Department of Religion, Non-Governmental Organizations, Universities in Indonesia. If necessary, it can also conduct comparative studies to other countries that are implementing deradicalization programs as well. Correctional Institutions can implement deradicalization programs that are more focused on mental and ideological changes by inviting various related parties to work together. The government must provide sufficient budget allocations for correctional institutions so that they can carry out the better deradicalization program.

Furthermore, it is necessary to take preventive rather than reactive measures, interagency approaches and strengthen public awareness so that they are not affected by terrorism and do not sympathize with the terrorist movement. The government should resolve the roots of local problems (as in the case of Poso and other conflict areas) and work together with relevant agencies to identify regions and communities affected by radical ideas to neutralize them. The existing environmental security system with the obligation to report to foreigners can be revived. On the education side, it is necessary to enrich the curriculum of religious education and citizenship education.

Deradicalization operates in a strategy that is carried out for ex-terrorists, ex-terrorist convicts, families, networks, and parties indicated as radical terrorists. The cycle of deradicalization is not only aimed at groups who are exposed to radical anarchist ideology after being processed by the law and determined by the law and after they return to the community, but also for those suspected of undergoing an investigation, investigation and trial process to obtain a verdict from a district court judge. Deradicalization is carried out through a holistic, comprehensive, integral and acculturative humanist approach. For the sake of mutual understanding, it demands serious attention from all levels of society and all components of the Indonesian nation. Because anarchist radicalism always uses religious language and symbols as a strategy to take the sympathy of people who do not understand. As a result, often the action collides with the teachings of religious rights and human rights (Idris, 2017).

Specific deradicalization programs for terrorist detainees have been implemented in various countries to carry out rehabilitation and to stop the spread of radicalization in prisons. One of the countries running the deradicalization program is Saudi Arabia with the PRAC program. Meanwhile, to foster British terrorist inmates have made a CONTEST (government counter-terrorism strategy ) and prevention strategy. On the one hand, deradicalization programs in several countries display similarities or at least have the same approach or pattern. Countries that apply similar patterns or approaches to deal with terrorist convicts include France, the Netherlands, Spain, the United Kingdom, and the United States. These countries' programs aim at security. While the Netherlands applies the principle of concentration in which all terrorist prisoners held in one place in high-security prisons in Vaugh. But other countries like Indonesia made a distribution of terrorist prisoners in 33 regional offices. As an alternative, in the Philippines, there is a deradicalization program, but the policy is designed and implemented differently throughout the penal system. For example, in the New Bilibid Prison (NBP), terrorist convicts are integrated with ordinary inmates, while in Metro Manila District Prison (MMDJ) terrorist inmates are separated from ordinary prisoners. In short, in the case of worldwide de-radicalization programs, each country has its approach and is similar or different from other countries' policies. 


\section{Conclusion}

The results showed that Indonesia took a serious action for the deradicalization of terorrist prisoners. The creation of BNPT to manage the deradicalization show some impact toward the ex-terrorist prisoner. The BNPT and Indonesian government implemented soft approach by various activities such as calling on scholars to come to lecture directly to prisoners. Take a subtle approach to terrorist prisoners to reshape their thinking about the struggle against religion. Meanwhile, the involvement of many institutions in the implementation of the program has several limitations in achieving rehabilitation objectives, such as lack of coordination and excessive sharing including through approaches to prison prisoners who call on religious leaders to provide enlightenment or deliver speeches. This activity is usually supported by MUI. There is also a deradicalization program with psychologically refined strategies so that terrorists rethink their understanding of fighting for religion.

The process of deradicalization requires decent state conditions, namely conditions that provide a sense of security and welfare for its people in various aspects of life. In such conditions of state life, radical religious understanding, such as the belief that an Islamic state needs to be established, has the potential to lose its legitimacy.

The conclusion is that the development of the deradicalization of terrorist prisoners in Indonesia has been carried out by various parties, but based on the results of this study and previous research is still not optimal so it needs to be reviewed about the type or method of fostering deradicalization that is appropriate.

The suggestions that can be given related to the results of this study are that further research needs to be done to discuss more specifically the deradicalization programs that have been implemented in Indonesia. Further research is also suggested to examine the models and also the most effective deradicalization strategies. The author further suggests the use of other research methods to study the effectiveness of the deradicalization program.

Whereas the suggestions for this research are that a Specific Correctional Institution is needed to foster terrorism inmates in Indonesia. This is because the Permanent Procedure for the Treatment of High-Risk Prisoners is in fact, difficult to implement in the ordinary existing correctional institution. However, the establishment of a Specific Terrorism Correctional Institution, as well as narcotics, is not without risks and obstacles such as the fear that the Specific Terrorism Correctional Institution is becoming a school of terrorism, human resource constraints, and infrastructure. However, it is hoped that the Specific Terrorism Correctional Institution can make the fostering focus of terrorism prisoners better.

\section{Acknowledgment}

The author would like to thanks the Correctional Polytechnic for providing the opportunity and encouragement to make this research article. The author also thanks the parents and colleagues who have helped in the completion of this article. The author realizes that there are still shortcomings in this article therefore the author expects suggestions and constructive criticism from all readers. Hopefully this article can have positive implications for all parties.

\section{References}

Ashour, O. (2009). Deradicalization Islamist Militants. SAGE Publications Ltd. Bilken, R., \& Bodgdan. (2001). Penelitian Kualitatif. Allyn and Bacon. BNPT. (2013). Blueprint deradikalisasi. (not Publish)

CNN. (2019). Peneliti: Cuma 30 Persen Teroris Insaf karena Deradikalisasi. https://www.cnnindonesia.com/nasional/20190710182004-20-410985/peneliti-cuma-30-persenteroris-insaf-karena-deradikalisasi 
Ditjenpas. (2020). Data Terakhir Jumlah Penghuni Per-UPT.

EL-Said. (2017). Deradicalization: Experience in Europe and the Arab World. IEMed Mediterranean Yearbook.

Horgan, J. (2008). Interviewing Terrorists (pp. 73-99). https://doi.org/10.1007/978-0-387-71613-8_4

ICG. (2012). How Indonesian Extremists Regroup. https://www.crisisgroup.org/asia/south-eastasia/indonesia/how-indonesian-extremists-regroup

Idris, I. (2017). Membumikan Deradikalisasi: Soft Approach Model Pembinaan Terorisme Dari Hulu Ke Hilir Secara Berkesinambungan (1st ed.). Daulat Press.

Isnanto, S. H. (2018). Berbagai Masalah Dan Tantangan Radikalisasi Dan Deradikalisasi Terorisme Di Indonesia. Jurnal Pertahanan \& Bela Negara, 5(2). https://doi.org/10.33172/jpbh.v5i2.366

Kruglanski, \& Fishman. (2009). Psychological Factors in Terrorism and Counterterrorism: Individual, Group, and Organizational Levels of Analysis. Social Issues and Policy Review, 3(1), 1-44.

Mareta, J. (2018). Rehabilitasi Dalam Upaya Deradikalisasi Narapidana Terorisme. Masalah-Masalah Hukum, 47(4), 338. https://doi.org/10.14710/mmh.47.4.2018.338-356

Mariamah, M. (2013). Keberhasilan Semu Deradikalisasi di Indonesia. Global: Jurnal Politik Internasional, 15(2).

Moleong. (2007). Metodologi Penelitian Kualitatif. Rosdakarya.

Royani, M. (2013). Pendekatan Deradikalisasi Dan Peran Pemerintah Daerah Dalam Mendukung Program Pemolisian Masayarakat Guna Mencegah Pengaruh Terorisme Di Daerah. Jurnal Nestor.

Salenda, K. (2009). Analisis terhadap Praktek Terorisme atas Nama Jihad, . 26, 75-101.

Setara. (2012). Dari Radikalisme Menuju Terorisme: Studi Relasi dan Transformasi Organisasi Islam Radikal di Jawa Tengah dan D.I. Yogyakarta.

Suarda, I. G. W. (2016). A Literature Review On Indonesia's Deradicalization Program For Terrorist Prisoners. Mimbar Hukum, 28(3), 526. https://doi.org/10.22146/jmh.16682

Sukabdi, Z. A. (2015). Terrorism In Indonesia: A Review On Rehabilitation And Deradicalization. Journal of Terrorism Research, 6(2). https://doi.org/10.15664/jtr.1154

Suratman, Y. P. (2018). The Effectiveness of De-Radicalization Program in Southeast Asia: Does It Work? The Case of Indonesia, Malaysia, and Singapore. JAS (Journal of ASEAN Studies), 5(2), 135. https://doi.org/10.21512/jas.v5i2.4302

Suryani, T. (2017). Terorisme dan Deradikalisasi: Pengantar Memahami Fundamentalisme Islam dan Strategi Pencegahan Aksi Terorisme. Jurnal Keamanan Nasional. https://doi.org/https://doi.org/10.31599/jkn.v3i2.57

Syafiq, M. (2019). Deradicalisation and Disengagement from Terrorism and Threat to Identity: An Analysis of Former Jihadist Prisoners' Accounts. Psychology and Developing Societies. https://doi.org/https://doi.org/10.1177/0971333619863169

Conflict of Interest Disclosures:

The authors declare that they have no significant competing financial, professional or personal interests that might have influenced the performance or presentation of the work described in this manuscript.

Copyrights Holder: <Asdira $><2020>$

First Publication Right: BISMA The Journal of Counseling 